\title{
IMPLEMENTATION OF DYNAMIC ROUTING WITH OSPF (OPEN SHORTEST PATH FIRST) TECHNIQUE IN LOCAL AREA NETWORK (LAN) AT SMKN 2 TELUK KUANTAN
}

\author{
Marezi Handika ${ }^{1}$, Herwin ${ }^{2}$, Dwi Haryono ${ }^{3}$, Rometdo Muzawi ${ }^{4}$ \\ ${ }^{1}$ Program Studi Teknik Informatika, STMIK Amik Riau, Teluk Kuantan, Kuantan Singingi \\ ${ }^{2}$ Program Studi Manajemen Informatika, STMIK Amik Riau, Jl. Purwodadi Km 10 Panam, Pekanbaru \\ ${ }^{3,4}$ Program Studi Sistem Informasi, STMIK Amik Riau, Jl. Purwodadi Km 10 Panam, Pekanbaru
}

\begin{tabular}{l} 
Article Info \\
\hline Article history: \\
Received 18 May,2021 \\
Revised 11 June, 2021 \\
Accepted 11 June, 2021 \\
\hline
\end{tabular}

Keywords:

Routing

Link State (OSPF)

Quality of Service

\begin{abstract}
SMKN 2 Teluk Kuantan has 4 (four) main lines of internet network that have own configuration. Static routing applied at SMKN 2 Teluk kuantan for the four modems of the network has own area, because it is not under one control of the modem to the Router. Static Routing at SMKN 2 Teluk Kuantan is very possible to be damaged or trouble itself on network of each modem. Static routing problems are so complex formed of routing information into the routing table had been set manually by the network administrator. Dynamic Routing is very possible to be implemented at SMKN 2 Teluk Kuantan. where dynamic routing has a basic routing algorithm of dynamic routing. Dynamic Routing enters routing information into the routing table through exchanging information with other routers and creates routing tables dynamically, on dynamic routing network administrators will not enter the entry route manually into the routing table. Routing Open Short Path First (OSPF) is a type of routing protocol builds topology independently by choosing the best path then test network quality if the best path is in interference and perform Quality of Service (QoS) against realtime data
\end{abstract}

This is an open access article under the CC BY-SA license.

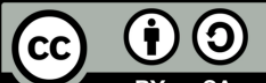

\section{Corresponding Author:}

Marezi Handika

Program Studi Teknik Informatika

STMIK Amik Riau

Email: marezihandika22@gmail.com

(C) The Author(s) 2021

\section{Introduction}

SMKN2 Teluk Kuantan is a vocational school located in Kuantan Singingi, Riau. This school has various kinds of departments. Each department need for internet access to support daily learning activities, both of students and teachers and other staff. To support these activities, SMKN 2 Teluk Kuantan has 4 (four) main lines of the Indihome internet network from the ISP. It divided in each places, namely the Office, Labor Room 1 and 2 and the Library Room. The four lines have indihome modems and their respective configurations for distribution to clients. Of the four network sources using Static Routing to network user underneath.

Static Routing was implemented at SMKN 2 Teluk Kuantan for the four modems of the network has own areas, because they are not under one modem control to the router. Static Routing at SMKN 2 Teluk Kuantan is possible to damage or trouble separately on the network of each modem, because it is not under the Routing control of the Router. The trouble will be detected if there is no internet access and will be repaired and it will take time so it will hamper school activities used internet network access. Static Routing cannot find another path or best path when there is a problem on the network, and there are divisions of four separate modem segments. 
The problem of static routing is so complex routing information entered into the routing table manually set by the network administrator. It is possible to change the routing methodology at SMKN 2 Teluk Kuantan because dynamic routing is possible to be implemented at SMKN 2 Teluk Kuantan. where dynamic routing has the basic routing algorithm of dynamic routing. Dynamic Routing enters routing information into the routing table by exchanging information with other routers and creates a routing table dynamically, the dynamic routing network administrator will not manually enter the route entry into the routing table. So that dynamic routing is the reason for the change from Static Routing at SMKN 2 Teluk Kuantan. Open Short Path First (OSPF) routing is a dynamic routing uses the LSDB (Link state Database) algorithm, which is a type of routing protocol builds topology independently by selecting the best path. So that network problems at SMKN2 Teluk Kuantan can be replaced by implementing the OSPF Routing.

\section{Research Method}

\subsection{Types of Research}

The research was used implementation research and experimentation research. It builds a network using the OSPF routing method and configuration has been implementing all the components involved in this research based on the research scenario. In this study, the OSPF method was applied, and became a benchmark in applying it to the field. Then it becomes a solution and recommendation for activists in the network world, especially in routing management for nature packet service.

\subsection{Design}

The topology used in this study can be seen in Figure 2. In this topology there is one laptop client unit, server, switch, UTP cable and four router units to be involved in the research. The four routers will be placed in each modem, they are in laboratories 1 and 2, offices and libraries.

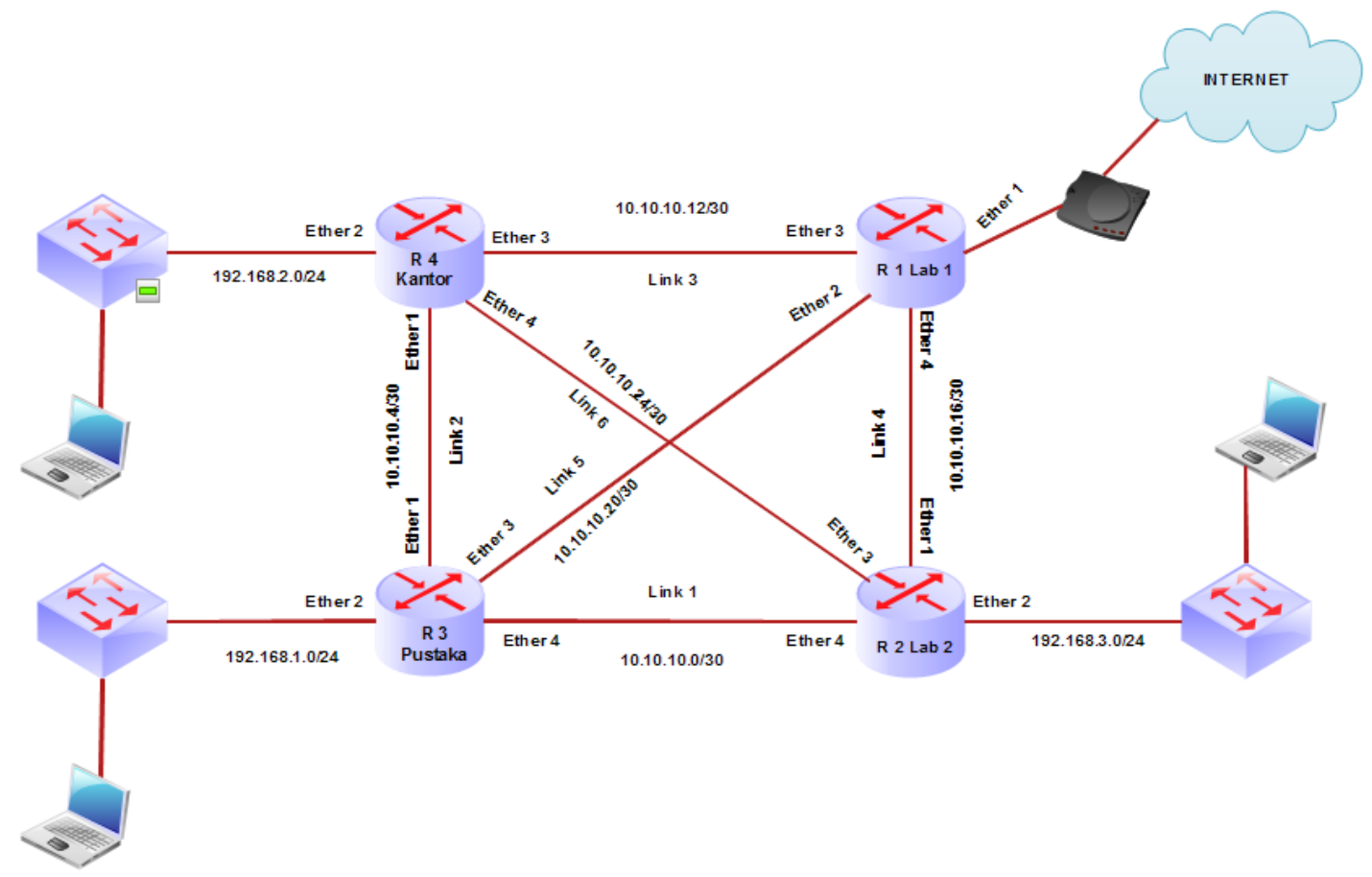

Gambar 2. Topologi Pengujian.(Testing Topology)

\subsection{Testing Method}

In this research, the network development is carried out using the OSPF routing method. The testing performs Quality of Service by seeing the OSPF method with the Quality of Service parameters in a normal network and abnormal network, in this case the main best path disconnection. Testing was done by comparing the changes in the bandwidth metric parameter in the OSPF routing protocol, and the testing of OSPF routing protocol based on the Cost metric, then testing of OSPF routing protocol based on the Cost Bandwidth metric. The tests include:

1. Measurement of Delay, Packet Loss and Throughput when there is no topology changes and there is topology changes on the network.

2. Router speed in making Routing Table when there is network topology changes or convergance time back. 


\section{Result and Discussion}

4.1 Quality of Service Testing

The OSPF routing protocol testing was conducted in this study based on testing of Quality of service (QoS) results when the client does video streaming, then sees the results of the QoS parameters. The test was carried out when there is no interference on the network and there is interference on the network in the down form in one link.

This test compares the results of QoS parameters based on the amount of Cost the data packet passes to the server. The next test is testing the length of time the router converges again when there is a network change or the main link of the packet path is broken, this test based on the client is streaming video. The OSPF routing protocol uses Cost as its metric, then the research scenario in obtaining research data, then an overview of the measurement method is in the table 1 .

Table 1.

OSPF Protocol Testing

\begin{tabular}{clccll}
\hline No & Router Path & Cost Total & Link Down & Compliment & \\
\hline 1 & $1-2$ & 20 & - & Best path & \\
2 & $2-3-1$ & 30 & 4 & Equal Cost & Load \\
& $2-4-1$ & 30 & 4 & Balancing & \\
3 & $2-3-4-1$ & 40 & 5,6 & Equal Cost & Load \\
& $2-4-3-1$ & 40 & 3,4 & Balancing & \\
\hline
\end{tabular}

The testing based on cost aims to compare the QoS value towards the total Cost of each network condition. This test also determines the QoS value when the client is streaming video. Almost the same as the QoS test above, the QoS test is to find the best value for QoS values. Testing based on this Cost only compares the average of each network condition and based on the total cost is.

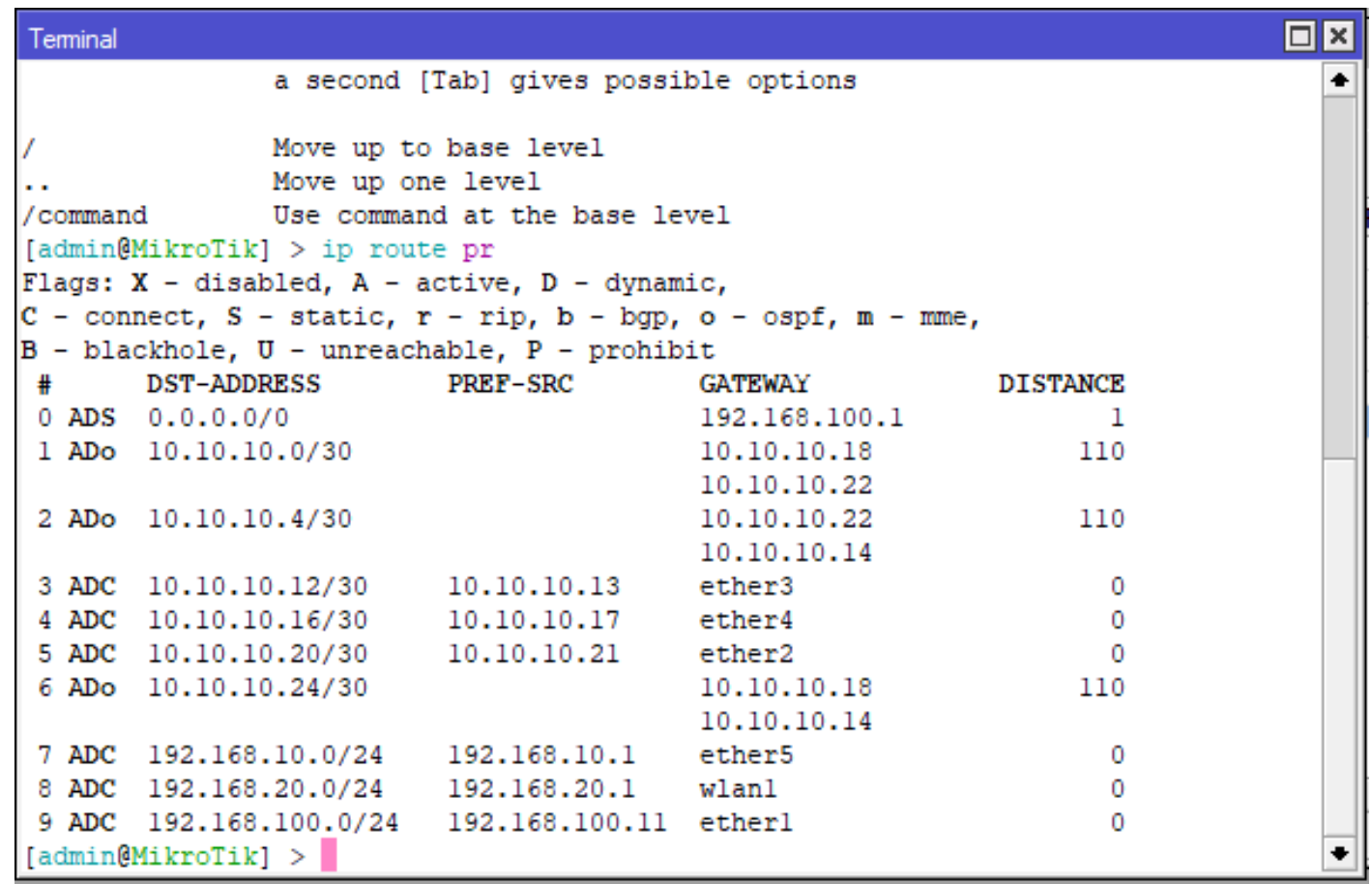

Gambar 3. IP Route Command

In the picture above, it can be seen that there are nine lists of links to DST-Address. There are three lists of links perform OSPF routing to reach the destination network with the label ADo (Active Dynamic OSPF). Meanwhile, the six link lists are also OSPF routing protocols, but they are labeled ADC (Active Dynamic Connected) because the IP Address of the interface is directly connected to R1_Lab_1. To go to network 0.0.0.0/0, 192.168.100.0 or network server, pass through gateway 192.168.100.1 with label ADS.

Table 2.

Compared QoS based on Cost 


\begin{tabular}{|c|c|c|c|c|c|}
\hline \multirow{3}{*}{ No } & & \multicolumn{4}{|c|}{ Cost } \\
\hline & \multirow[b]{2}{*}{ Router } & \multirow[b]{2}{*}{ Cost } & \multicolumn{3}{|c|}{ Average } \\
\hline & & & Delay (s) & Packet loss (\%) & $\begin{array}{c}\text { Throughput } \\
\text { (MBit/s) }\end{array}$ \\
\hline 1 & $2-3-1$ & \multirow{2}{*}{30} & 0,001815 & 0,065053 & 1,568 \\
\hline \multirow[t]{2}{*}{2} & $2-4-1$ & & 0,004380 & 0,037012 & 1,763 \\
\hline & Average & \multirow{4}{*}{40} & $\mathbf{0 , 0 0 3 0 9 7 5}$ & 0,0510325 & 1,665 \\
\hline 3 & $2-3-4-1$ & & 0,004587 & 0,030693 & 1,769 \\
\hline 4 & $2-4-3-1$ & & 0,004538 & 0,066852 & 1,914 \\
\hline \multicolumn{2}{|c|}{ Average } & & 0,0045625 & 0,0487725 & 1,841 \\
\hline
\end{tabular}

4.2 Testing the Routing Table Update Duration

In testing the duration of the routing table update by deciding the best path or link directly connected to the server. At the termination of the link the router will choose an alternative path listed in the routing table. This test by sending ICMP protocol packets. In this test used supporting application to find assessment parameters from testing the duration of the routing table update. To find the delay was used Wireshark. When there is a link break, the wireshark application can capture the data packet returns to the server by sending an ICMP packet. The following are the test results to get the delay in the routing table update process.

Table 3.

Update table Measurement

\begin{tabular}{|c|c|c|c|c|}
\hline NO & Condition & $\begin{array}{l}\text { Time since } \\
\text { reference or first } \\
\text { frame (star) }\end{array}$ & $\begin{array}{l}\text { Time since } \\
\text { reference or first } \\
\text { frame (finish) }\end{array}$ & Delay \\
\hline 1 & $\begin{array}{l}\text { R2 ether } 1 \text { and ether } 3 \text { Down } \\
\text { Path R2 - R3 - R1 }\end{array}$ & 2,031187000 & 31,828331000 & 29,797144 \\
\hline 2 & $\begin{array}{l}\text { R2 ether } 1 \text { and ether } 4 \text { Down } \\
\text { Path R2 - R4 - R1 }\end{array}$ & 6,09933800 & 27,587525 & 21,488187 \\
\hline 3 & $\begin{array}{l}\text { R2 ether } 1 \text {, ether } 4 \text { and R4 ether } 3 \\
\text { Down } \\
\text { Path R2 - R3 - R4 - R1 }\end{array}$ & 5,078108000 & 258,64801000 & 253,569902 \\
\hline 4 & $\begin{array}{l}\text { R2 ether } 1 \text { and R3 ether } 4 \text { Down } \\
\text { Path R2 - R4 - R3 - R1 }\end{array}$ & 5,078023000 & 37,737917000 & 32,659894 \\
\hline
\end{tabular}

4.3 Testing to achieve Convergence

This test is to see a comparison when there is changes in the network, the failure of the main link/best path or there is network down to stable or convergence. Then to see the effects of real time data. It means on video streaming is being used by the client. This test also involves ICMP (Internet Control Message Protocol) packets to see new paths used, and to see routers the data packet passes through. This test used the Wireshark application by sending ICMP packets. Here's one of the images in this test. 
Table 4.

ICMP Packets

\begin{tabular}{clccc}
\hline NO & \multicolumn{1}{c}{ CONDITION } & DOWN TIME & UP TIME & $\begin{array}{c}\text { TIME OF } \\
\text { DIFFERENTIATE }\end{array}$ \\
\hline $\mathbf{1}$ & $\begin{array}{l}\text { R2 ether 1 and ether 3 Down } \\
\text { Path R2 - R3 - R1 }\end{array}$ & 12.29 .11 & 12.30 .06 & 00.00 .55 \\
$\mathbf{2}$ & $\begin{array}{l}\text { R2 ether 1 and ether 4 Down } \\
\text { Path R2 - R4 - R1 }\end{array}$ & 12.39 .06 & 12.40 .31 & 00.01 .25 \\
$\mathbf{3}$ & $\begin{array}{l}\text { R2 ether 1, ether 4 and R4 ether 3 } \\
\text { Down }\end{array}$ & 12.49 .15 & 12.54 .20 & 00.05 .05 \\
$\begin{array}{l}\text { Path R2 - R3 - R4 - R1 } \\
\text { R2 ether 1 and R3 ether 4 Down }\end{array}$ & 13.16 .43 & 13.18 .06 & 00.01 .23 \\
\hline
\end{tabular}

\section{Conclusion}

From the result of this study, it was conclude for the testing to achieve convergence when there is topology changes or network changes based on the test scenario, it takes at least 55 seconds for the network return to normal until 5 minutes. For the testing the measurement of the update table, it also has a minimum delay of 21 seconds to 253 seconds, the largest time required when there is changes in topology and speed of the router in updating the table based on the test scenario. Testing based on Quality of Service (QoS) also has differences based on the amount of costs that the packet passes to destination network. For the total cost of 30 , it has average delay of 0.0030975 second and 0.0045625 second for the cost of 40 . For packet loss costs 30 get result of $0.0510325 \%$ and cost of $400.0487725 \%$. Meanwhile, for throughput, the result is 1.665 $\mathrm{Mbit} / \mathrm{s}$ for cost 30 and $1.841 \mathrm{Mbit} / \mathrm{s}$ for cost 40. From the QoS test, the smallest cost has the smallest delay and throughput.

\section{References}

[1] Achmad. (2015). Implementasi Routing Protocol Open Shortest Path Firs (OSPF) pada model topology Ring. Jurnal Program Studi Teknik Informatika, Universitas Indraprasta PGRI

[2] Forouzan, Behrouz A, (2012). Data Communications and Networking, Fifth Edition, New York: McGraw Hill

[3] Hasanah, Febri U dan Mubarakah, Naema (2014). Analisis kinerja routing dinamis dengan teknik RIP (routing information protocol) pada topologi Ring dalam jaringan lan (local area network) Menggunakan cisco packet tracer. Jurnal Teknik Telekomunikasi Universitas Sumatera Utara

[4] Kader. Dave P (2014). Analisa Performansi Algoritma Routing Di Jaringan Komputer Unsrat. Journal Teknik Elektro dan Komputer Universitas Sam Ratulangi

[5] Novendra, Yoldi (2018). Analisa Perbandingan Kinerja Routing OSPF dan EIGRP. Journal IT Journal Research and Development. Universitas Islam Riau

[6] Perdana. Pendi (2019). Implementasi Dynamic Routing OSPF Dengan Metode Singe Area pada SMK Mulia Tangerang. Jurnal Manajemen Informatika. Universitas Budi Luhur

[7] Pratama, I Putu Agus Eka. (2014). Handboook Jaringan Komputer. Bandung: Informatika

[8] Rifiani. Vina. (2010). Analisa perbandingan metode routing distance Vector dan link state pada jaringan packet. Jurnal Teknik Telekomunikasi Politeknik Elektronika Negeri Surabaya

[9] Romadhon, Pearl Pratama. (2014). Analisis kinerja jaringan wireless lan menggunakan metode QoS dan RMA pada PT Pertamina Ep Ubep Ramba (Persero). skripsi teknik informatika Universitas Bina Darma

[10] David Marcus. Ronald. (2018). Penerapan Open Shortest Path First (OSPF) untuk Membangun Jaringan Berskala Besar Berbasis Mikrotik. Tugas Akhir. Fakultas Teknologi Informasi. Universitas Mardeka Malang

[11] Safitri, Rosydina (2010). Implementasi dan Analisa Perbandingan QoS pada jaringan VPN berbasis MPLS menggunakan Routing Protokol RIPv2, EIGRP dan OSPF terhadap Tunneling IPSEC untuk Layanan IP-Based Video Conference. Skripsi Teknik Elektro Universitas Indonesia. 
[12] Sasongko Jati, Wahyu (2018) Perbandingan Kinerja Protocol Routing Open Shortest Path First (OSPF) dan Routing Information Protocol (RIP) Menggunakan Simulator Cisco Packet Tracer. Fakultas Ilmu Komputer, Universitas Brawijaya

[13] M. H. Siregar, "Design of Wireless Computer Network Infrastructure in Implementation of Kemendikbud Distributed Information Systems in Singingi Kuantan Islamic University,” J. Mantik, vol. 4, no. November, pp. 31-38, 2020, [Online]. Available: http://iocscience.org/ejournal/index.php/mantik/article/view/882/595.

[13] Tanenbaum, Andrew S (2011). Computer Networks, Fifth Edition. Boston: Prentice Hall

[14] Towidjojo, Rendra. (2012). Konsep dan Implementasi Routing dengan Router Mikrotik $100 \%$ Connected. Yogyakarta. Jasacom

[15] (2013). Konsep dan Implementasi Routing dengan Router Mikrotik $200 \%$ Connected. Yogyakarta. Jasacom

[16] Villasica, Yovie Dwi (2014). Analisis kinerja routing dinamis dengan teknik ospf (open shortest path first) pada topologi mesh dalam Jaringan local area network (lan) menggunakan cisco Packet tracer. Jurnal Teknik Telekomunikasi Universitas Sumatera Utara

[17] Yugianto,Gin-Gin. dan Rahman (2012). Router Teknologi, Konsep, Konfigurasi dan Troubleshooting. Jakarta. Informatika

[18] Wahono, Romi S. (2006), Konsep Subnetting, Siapa Takut?

[19] http://romisatriowahono.net/konsep-subnetting (diakses pada januari 2021)

[20] http://www.videolan.org/vlc/streaming.html (diakses pada Januari 2021)

[21] ETSI. (1999). Telecommunications and Internet Protocol Harmonization Over Networks (TIPHON) General aspects of Quality of Service $(\mathrm{QoS})$ 